(ISSN Cetak 1978-6573) (ISSN Online 2477-300X)

\title{
PENGARUH PROFITABILITAS, LIKUIDITAS, LEVERAGE, UMUR OBLIGASI \\ DAN UKURAN PERUSAHAAN TERHADAP PERINGKAT OBLIGASI PADA SEKTOR KEUANGAN YANG TERDAPAT DI BEI TAHUN 2015-2018
}

\author{
Akhmad Darmawan', Yudith Foran Al Fayed ${ }^{2}$, Fatmah Bagis 3 , Bima Cininttya \\ Pratama $^{4}$ \\ Fakultas Ekonomi dan Bisnis, Universitas Muhammadiyah Purwokerto \\ akhmaddarmawan@ump.ac.id ${ }^{1}$
}

\begin{abstract}
ABSTRAK
Penelitian ini bertujuan untuk mengetahui pengaruh profitabilitas, likuiditas, leverage, umur obligasi dan ukuran perusahaan terhadap peringkat obligasi pada sektor keuangan yang terdapat di Bursa Efek Indonesia pada periode 2015 - 2018 menggunakan 86 sampel perusahaan menggunakan teknik purposive sampling. Sedangkan, teknik pengumpulan data yang digunakan dalam penelitian ini adalah statistik deskriptif, uji asumsi klasik, regresi linier berganda dan hypothesis testing. Hasil analisis menggunakan regresi menunjukkan bahwa profitabiltas berpengaruh negatif dan tidak signifikan terhadap peringkat obligasi, likuiditas berpengaruh positif dan signifikan terhadap peringkat obligasi, leverage berpengaruh positif dan signifikan terhadap peringkat obligasi dan umur obligasi berpengaruh positif dan signifikan terhadap peringkat obligasi. Sedangkan, ukuran perusahaan berpengaruh negatif dan tidak signifikan terhadap peringkat obligasi.
\end{abstract}

Keywords: Profitability, Liquidity, Leverage, Age of Bonds, Firm Size, Bond Rating

\begin{abstract}
This study aims to examine the effects of profitability, liquidity, leverage, age of bonds and firm size toward bond rating in the financial sectors listed in Indonesia Stock Exchange during 2015-2018 using 86 samples chosen by purposive sampling. Meanwhile, data analysis techniques used in this study were descriptive statistics, classic assumption tests, multiple linear regression analysis and hypothesis testing. The results of data analysis using regression analysis showed that profitability had not a significant negative effect on bond rating in financial sectors, liquidity had a significant positive effect on bond ratings in financial sectors, leverage had a significant positive effect on bond rating in financial sector and age of bond had a significant negative effect on bond rating in financial sectors. While, firm size had a significant negative effect on bond rating in financial sectors.
\end{abstract}

Keywords: Profitability, Liquidity, Leverage, Age of Bonds, Firm Size, Bond Rating

\section{PENDAHULUAN}

Di dunia perkembangan tekhnologi semakin maju dan sistem perekonomian yang semakin komplek, akibatnya banyak permasalahanpermasalahan yang timbul. Salah satunya pada bank sentral di dunia, yang melakukan kebijakan moneter, termasuk bank sentral AS yang pada Juli 2019 telah menurunkan suku bunga kebijakannya. Akibat dari dampak ekonomi global, Indonesia mengalami berbagai masalah ekonomi yang bervariatif. Ruang penguatan pasar obligasi tak lagi tersedia. Adapun, pada perdagangan sebelumnya, pasar ditutup melemah meskipun BI mengumumkan penurunan suku bunga acuan ke level $5,75 \%$. Seharusnya penurunan suku bunga BI menjadi sentimen positif pada 


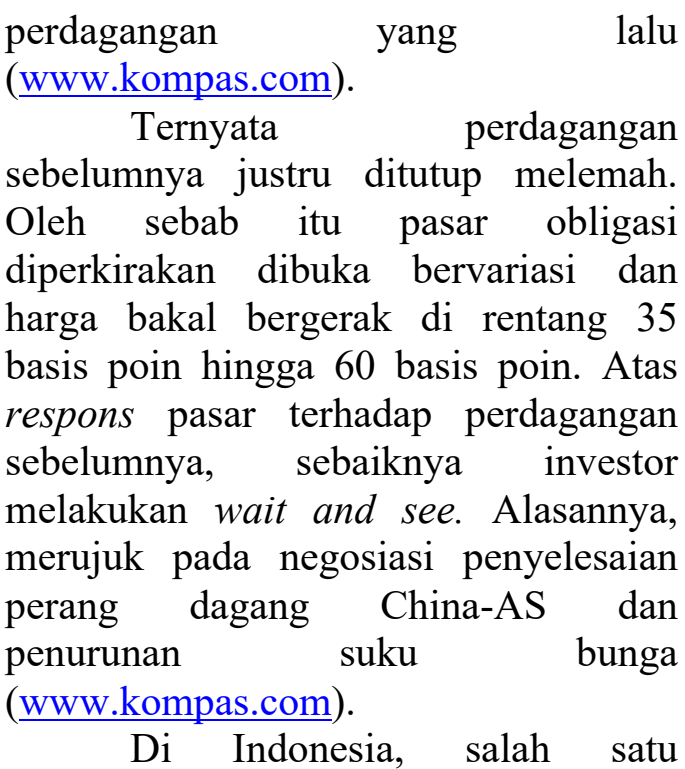
lembaga pemeringkat yang paling banyak dijadikan rujukan adalah PT. PEFINDO (Pemeringkat Efek Indonesia). PEFINDO secara rutin mengumumkan hasil pemeringkatannya setiap bulan yang dapat dilihat di beberapa harian bisnis nasional atau langsung dari situs PEFINDO di new pefindo.com. Para lembaga pemeringkat menggunakan sebagai faktor untuk menilai dan memberikan peringkat kepada obligasi perusahaan. Salah satu faktor yang digunakan oleh lembaga pemeringkat adalah informasi akuntansi yang tersedia. Informasi ini diberikan dalam bentuk laporan keuangan perusahaan.

Ada beberapa penelitian yang menguji faktor-faktor yang mempengaruhi peringkat obligasi antara lain profitabilitas. Profitabilitas merupakan kemampuan manajemen untuk memperoleh laba (Utari. (2014). Adapun penelitian terdahulu profitabilitas mempengaruhi peringkat obligasi menurut Widiyastuti (2016), Henny (2016), Suwarti \& Kurniawan (2015), menyatakan bahwa profitabilitas yang dinilai menggunakan ROA berpengaruh positif signifikan terhadap peringkat obligasi. Berbeda dengan penelitian variabel lain yaitu variabel likuiditas. Likuiditas merupakan kemampuan perusahaan memenuhi semua kewajibannya yang jatuh tempo (Utari (2014). Menurut hasil penelitian Azani, khairunnisa \& Dillak (2017), Hidayat (2018), bahwa hasil pengujian dengan menggunakan regresi logistik membuktikan bahwa variabel likuiditas yang diukur dengan menggunakan indikator current ratio pada obligasi yang diperingkat oleh PT. PEFINDO tahun 2011 sampai tahun 2015 berpengaruh positif signifikan terhadap peringkat obligasi. Variabel selanjutnya terdapat variabel leverage merupakan gambaran kemampuan suatu perusahaan dalam memenuhi dan menjaga kemampuannya untuk selalu mampu memenuhi kewajibannya dalam membayar utang secara tepat waktu, Fahmi. (2013). Pada variabel leverage menurut Azani khairunnisa \& Dillak.. (2017), Widiyastuti (2016), Dwitayanti (2018), Mardiyati dkk. (2015), Sakinah dkk. (2017), menyatakan bahwa leverage berpengaruh positif signifikan terhadap peringkat obligasi. Variabel ke-empat ada umur obligasi. Umur obligasi merupakan maturity value atau disebut juga dengan nilai jatuh tempo adalah nilai yang dijanjikan akan dibayar pada saat obligasi jatuh tempo, Anandasari \& Sudjarni, (2017). Sedangkan penelitian menurut Faizah (2019) dan Widiastuti \& Rahyuda (2016), menyatakan bahwa maturity berpengaruh positif signifikan terhadap peringkat obligasi. Pada variabel independen terakhir yaitu ukuran perusahaan merupakan besar kecilnya suatu perusahaan yang dapat dinyatakan dengan total asset ataupun dengan total penjualan bersih. Semakin besar total asset maka semakin besar pula ukuran suatu perusahaan. Semakin besar asset maka semakin besar modal yang ditanam, sementara semakin banyak perputaran utang dalam perusahaan (Hery, 2017). Menurut Sari \& Badjra (2016), Pinanditha \& Suryantini (2016), 
menyatakan bahwa ukuran perusahaan yang diproksikan dengan size berpengaruh positif signifikan terhadap peringkat obligasi. Berikut beberapa penjelasan terkait obligasi, peringkat obligasi, faktor-faktor yang mempengaruhi peringkat obligasi.

\section{A. Obligasi}

Semakin berkembangnya ilmu pengetahuan, para ekonom mendefinisikan obligasi sangat beragam namun secara keseluruhan memiliki makna atau pengertian yang hampir sama. Menurut Fahmi (2013:179), obligasi merupakan suatu surat berharga yang dijual kepada publik, dimana disana dicantumkan berbagai ketentuan yang menjelaskan berbagai hal seperti nilai nominal, tingkat suku bunga, jangka waktu, nama penerbit dan beberapa ketentuan lainnya yang terjelaskan dalam undangundang yang disahkan oleh lembaga yang terkait.

\section{B. Peringkat Obligasi (Bonds Rating)}

Secara umum bond rating merupakan suatu tingkat pengukuran kualitas dan keamanan dari sebuah bond yang didasarkan oleh sebuah kondisi financial dari bond issuer. Menurut Hartono \& Jugiyanto (2017), peringkat obligasi adalah simbol-simbol karakter yang diberikan oleh agen peringkat untuk menunjukan risiko dari obligasi. Secara spesifik, bond rating digunakan sebagai proksi dari risiko obligasi. Tujuan utama proses rating adalah memberikan informasi akurat mengenai kinerja keuangan, posisi bisnis industri perseroan yang menerbitkan surat hutang (obligasi) dalam bentuk peringkat pada calon investor.

\section{Faktor-Faktor \\ Mempengaruhi Obligasi \\ yang \\ Peringkat}

Banyak faktor-faktor yang mempengaruhi peringkat obligasi, dalam penelitian ini peneliti mengambil beberapa variablevariabel yang mempengaruhi peringkat obligasi antara lain sebagai berikut:

1. Profitabilitas

Menurut Fahmi (2014) menyatakan bahwa rasio ini mengukur efektivitas manajemen secara keseluruhan yang ditujukan oleh besar kecilnya tingkat keuntungan yang diperoleh dalam hubungannya dengan penjualan maupun investasi. Semakin baik rasio profitabilitas maka semakin baik menggambarkan kemampuan tingginya perolehan keuntungan perusahaan. Rasio profitabilitas menggambarkan kemampuan perusahaan mendapatkan laba melalui semua kemampuan dan sumber yang ada seperti kegiatan penjualan, kas, modal, jumlah karyawan, jumlah cabang, dan sebagainya. Menurut teori keagenan (Agency Theory) merupakan suatu kondisi yang terjadi pada suatu perusahaan dimana pihak perusahaan sebagai pelaksana yang disebut sebagai agen dan investor sebagai principal, membangun suatu kontrak kerjasama yang disebut dengan "nexus of contract", kontrak kerjasama ini berisi kesepakatan-kesepakatan yang menjalankan bahwa pihak perusahaan harus bekerja secara maksimal untuk memberi kepuasan laba kepada investor (Fahmi, 2014). 
2. Likuiditas

$$
\text { Likuiditas (licuidity }
$$

ratio) adalah kemampuan suatu perusahaan memenuhi kewajiban jangka pendeknya secara lancar dan tepat waktu. Sama halnya dengan pendapat Utari dkk, (2014) menyatakan bahwa likuiditas merupakan kemampuan perusahaan memenuhi semua kewajibannya yang jatuh tempo. Sesuai teori signaling, likuiditas yang tinggi dapat memberikan sinyal kepada investor bahwa perusahaan memiliki kemampuan untuk melakukan kewajibannya dalam jangka relatif pendek. Kuatnya kondisi keuangan perusahaan tersebut dapat menandakan bahwa kemungkinan pelunasan kewajiban jangka panjangnya juga semakin baik, sehingga nantinya akan mempengaruhi peringkat obligasi yang akan diberikan.

Kemampuan itu dapat diwujudkan bila jumlah harta lancar lebih besar daripada utang lancar. Contoh membayar listrik, telepon, air, gaji karyawan, gaji teknisi, gaji lembur, tagihan telepon, dan sebagainya. Rasio likuiditas dapat diartikan sebagai kemampuan perusahaan dalam melunasi sejumlah utang jangka pendek, umumnya kurang dari satu tahun, Harmono, (2011). Karena itu rasio likuiditas sering disebut dengan short term liquidity. Rasio likuiditas secara umum dibagi dua yaitu current ratio dan quick ratio.

\section{Leverage}

$$
\begin{aligned}
& \text { Rasio leverage disebut } \\
& \text { juga sebagai rasio solvabilitas, } \\
& \text { menurut Fahmi, (2013) }
\end{aligned}
$$

merupakan gambaran kemampuan suatu perusahaan dalam memenuhi dan menjaga kemampuannya untuk selalu mampu memenuhi kewajibannya dalam membayar utang secara tepat waktu. Rasio leverage yang umum dipakai antara lain adalah debt to asset ratio, debt to equity ratio, time interest earned ratio, fixed charge coverage ratio dan debt service coverage.

Semakin besar rasio ini menunjukan bahwa semakin besar pula porsi penggunaan utang dalam membiayai investasi pada modal, yang berarti pula resiko keuangan meningkat. Menurut Hamida (2017), menyatakan bahwa "semakin besar leverage perusahaan, semakin besar risiko kegagalan perusahaan. Semakin rendah leverage perusahaan, semakin baik peringkat yang diberikan terhadap perusahaan". Hal ini mengindikasikan perusahaan dengan tingkat leverage yang tinggi cenderung memiliki kemampuan yang rendah dalam memenuhi kewajibannya.

Semakin tinggi rasio ini berarti sebagian besar aset didanai dari hutang. Kondisi tersebut menyebabkan perusahaan dihadapkan pada default risk atau peringkat obligasi yang rendah. Semakin tinggi leverage, semakin besar risiko kegagalan perusahaan. Dengan demikian, semakin rendah leverage perusahaan maka akan semakin tinggi peringkat yang diberikan pada perusahaan.

Nilai leverage yang tinggi memberikan sinyal 
kepada investor adanya ketidakpastian kemampuan perusahaan dalam melaksanakan utangnya pada saat jatuh tempo. Investor tidak ingin menanggung kerugian atau resiko yang mungkin terjadi jika memilih investasi pada obligasi non investment grade atau memiliki angka leverage yang tinggi. Hal ini mengindikasikan tingginya tingkat leverage mengakibatkan perusahaan dihadapkan pada risiko kegagalan perusahaan karena cenderung memiliki kemampuan yang rendah dalam melunasi utangnya dan peringkat obligasi menjadi turun.

4. Umur Obligasi

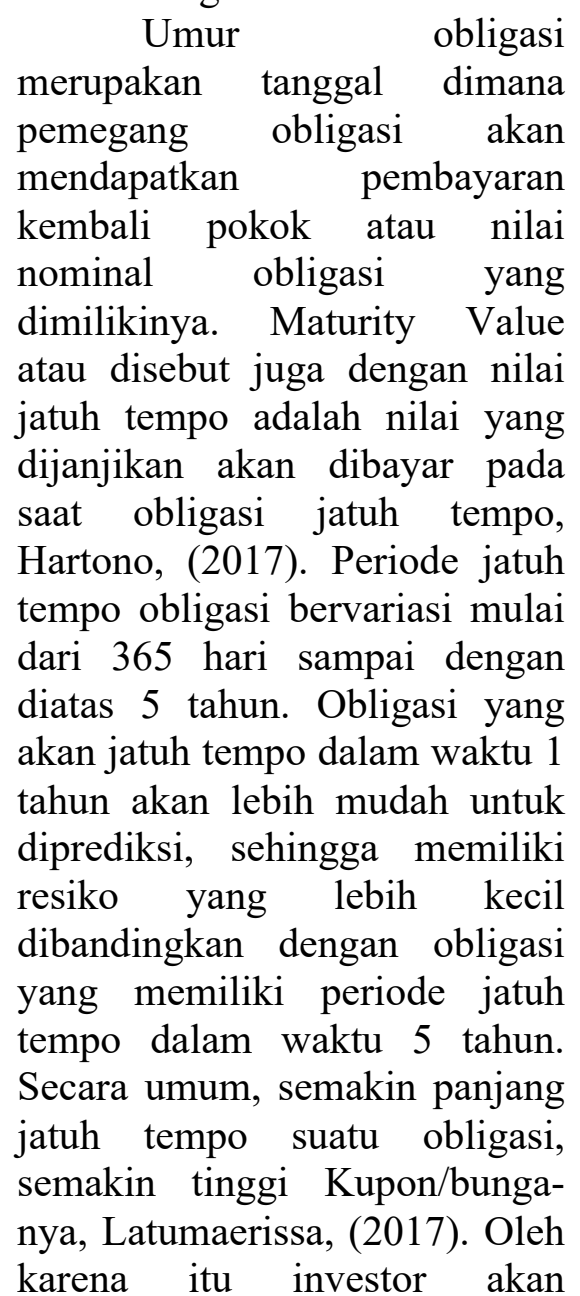

memilih obligasi dengan umur pendek dibanding dengan obligasi berumur panjang. Karena obligasi yang berumur pendek memiliki resiko yang kecil dibanding dengan obligasi berumur panjang. Umur obligasi yang pendek ternyata menunjukan peringkat obligasi yang investment grade. Hal ini menyebabkan umur obligasi dapat memberikan sinyal kepada investor agar dapat berinvestasi obligasi.

\section{Ukuran Perusahaan}

Ukuran perusahaan adalah suatu skala dimana dapat diklasifikasikan besar kecilnya perusahaan menurut berbagai cara antara lain dengan total asset, Hery, (2017). Ukuran perusahaan menggambarkan besar kecilnya suatu perusahaan yang dapat dinyatakan dengan total asset ataupun dengan total penjualan bersih. Semakin besar total asset maka semakin besar pula ukuran suatu perusahaan. Semakin besar asset maka semakin besar modal yang ditanam, sementara semakin banyak perputaran utang dalam perusahaan.

Brigham dan Houston menyatakan ukuran perusahaan sebagai rata-rata total penjualan bersih untuk tahun yang bersangkutan sampai beberapa tahun, ukuran perusahaan juga merupakan karakteristik suatu perusahaan dalam hubungannya dengan struktur perusahaan, Sari, (2016). Hasil penelitian menunjukkan bahwa semakin besar ukuran perusahaan, maka semakin tinggi peringkat obligasi yang diberikan, hal ini disebabkan oleh tingginya 
tingkat kepercayaan investor terhadap perusahaan dengan ukuran yang besar. Perusahaan besar memiliki posisi yang kuat pada masing-masing industri yang digeluti sehingga mendukung peringkat obligasi yang diberikan (Sari, 2016).

Perusahaan yang besar dianggap mempunyai risiko yang lebih kecil dibandingkan dengan perusahaan yang lebih kecil. Alasannya adalah karena perusahaan yang besar dianggap lebih mempunyai akses ke pasar modal, sehingga dianggap mempunyai risiko yang lebih kecil, Hartono, (2017). Ukuran perusahaan yang tinggi dapat menggambarkan bahwa perusahaan tersebut telah beroperasi dengan baik sehingga dapat menghasilkan aset dan laba yang tinggi, sehingga pasar akan mau membayar lebih mahal karena percaya akan mendapatkan pengembalian yang menguntungkan dari perusahaan tersebut. Sesuai dengan teori sinyal bahwa perusahaan mempunyai dorongan untuk memberikan informasi laporan keuangan pada pihak eksternal, termasuk laba dan aset yang tinggi dapat meyakinkan serta memberi sinyal kepada investor bahwa perusahaan tersebut dapat memberikan profit dengan baik, sehingga nantinya dapat mempengaruhi peringkat obligasi yang akan diberikan.

Berdasarkan uraian latar belakang yang telah dikemukakan, maka penulis merumuskan masalah dalam penelitian ini adalah sebagai berikut:

a. Apakah profitabilitas berpengaruh positif signifikan terhadap peringkat obligasi?

b. Apakah likuiditas berpengaruh positif signifikan terhadap peringkat obligasi?

c. Apakah leverage berpengaruh positif signifikan terhadap peringkat obligasi?

d. Apakah umur obligasi berpengaruh negatif signifikan terhadap peringkat obligasi?

e. Apakah ukuran perusahaan berpengaruh positif signifikan terhadap peringkat obligasi?

Adapun bagan kerangka konseptual dalam penelitian ini dapat dilihat pada skema gambar di bawah ini: 


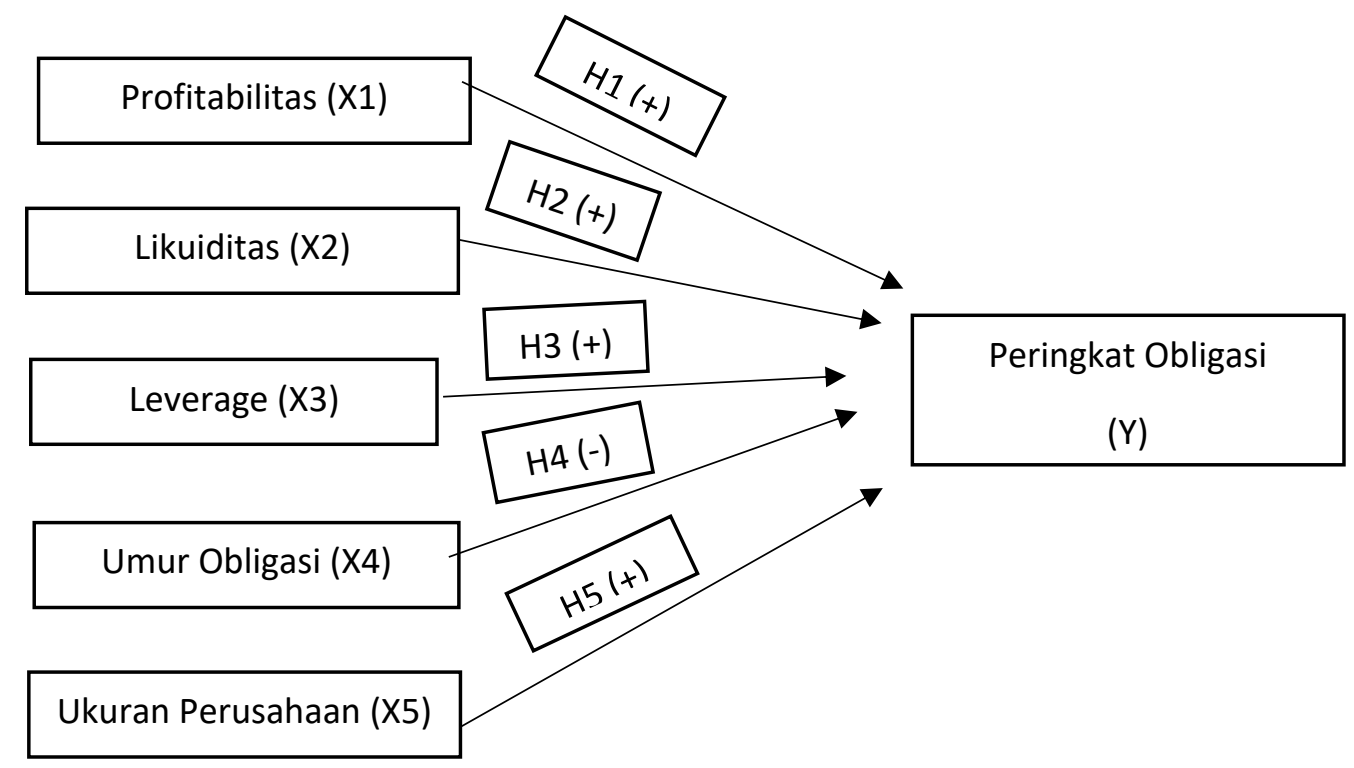

Gambar 1. Bagan Kerangka Pemikiran

Hipotesis dalam penelitian ini sebagai berikut:

H1: Profitabilitas berpengaruh positif signifikan terhadap peringkat obligasi.

H2: Likuiditas berpengaruh positif signifikan terhadap peringkat obligasi.

H3: Leverage berpengaruh positif signifikan terhadap peringkat obligasi.

H4: Umur obligasi berpengaruh negatif signifikan terhadap peringkat obligasi.

H5: Ukuran perusahaan berpengaruh positif signifikan terhadap peringkat obligasi.

\section{METODE PENELITIAN}

\section{A. Jenis Penelitian}

Berdasarkan karakteristik masalah, penelitian ini termasuk penelitian asosiatif. Penelitian asosiatif merupakan penelitian yang bertujuan untuk mengetahui pengaruh ataupun juga hubungan antara dua variabel atau lebih. Penelitian ini menggunakan penelitian kuantitatif, penelitian kuantitatif adalah penelitian dengan memperoleh data yang berbentuk angka atau data kualitatif yang diangkakan (Suliyanto, 2018).

\section{B. Populasi dan Sampel}

Populasi merupakan keseluruhan elemen yang hendak diduga karakteristiknya yang terdiri atas obyek atau subyek dan mempunyai karakteristik tertentu yang ditetapkan oleh peneliti untuk mempelajari dan kemudian ditarik kesimpulannya (Suliyanto, 2018). Populasi yang menjadi objek dalam penelitian ini adalah sektor keuangan yang terdaftar di Bursa Efek Indonesia (BEI) tahun 20152018 sebanyak 90 perusahaan, kemudian diseleksi menjadi beberapa sampel sehingga menjadi lebih mudah untuk peneliti dalam melakukan penelitian. Sampel dipilih dengan menggunakan teknik purposive sampling. Kriteria penentuan sampel dalam penelitian ini:

1. Perusahaan sektor keuangan yang menerbitkan laporan keuangan di Bursa Efek 
Indonesia (BEI) pada tahun 2015-2018.

2. Perusahaan menerbitkan laporan keuangan per 31 Desember dalam satuan mata uang rupiah, perusahaan yang dalam annual report-nya tidak mengalami kerugian selama periode 20152018.

3. Perusahaan yang menerbitkan obligasi selama periode 20152018.

4. Perusahaan korporasi sektor keuangan yang obligasinya masih beredar pada tahun 20152018.

\section{Jenis, Sumber Data dan Teknik Pengumpulan Data}

Data merupakan bahan mentah dari informasi, sehingga informasi adalah hasil pengolahan data yang dapat digunakan untuk menambah pengetahuan bagi penerimanya (Sugiyono, 2013; Suliyanto, 2018). Penelitian ini termasuk penelitian menggunakan data sekunder. Jenis penelitian ini menggunakan data kuantitatif, data dalam bentuk angka yaitu berupa laporan keuangan tahunan sektor keuangan yang terdaftar di Bursa Efek Indonesia tahun 2015-2018. Dalam penelitian ini menggunakan regresi panel. Data panel adalah data yang memiliki jumlah crossection dan jumlah time-series. Ada dua macam panel yang termasuk data panel yaitu panel balance dan panel unbalance. Dalam penelitian ini menggunakan data panel unbalance, yang merupakan keadaan dimana unit cross-sectional memiliki jumlah observasi time series yang tidak sama. Data yang digunakan dalam penelitian adalah laporan keuangan untuk periode 2015 sampai dengan 2018. Sampel penelitian ini juga menggunakan data dari PT. PEFINDO dan BEI periode 2015 sampai dengan 2018.

\section{Variabel Penelitian}

Variabel adalah karakterisrik objek penelitian yang nilainya bervariasi dari satu subjek ke subjek lainnya atau dari satu waktu ke waktu yang lainnya. Maka syarat untuk menjadi sebuah variabel adalah sesuatu menjadi fokus perhatian, dapat diamati, dapat diukur, dan memiliki variasi (Suliyanto, 2018). Variabel yang digunakan oleh peneliti adalah variabel dependen dan variabel independen. Peneliti menggunakan variabel profitabilitas, likuiditas, leverage, umur obligasi dan ukuran perusahaan sebagai variabel independen. Variabel dependen yang peneliti gunakan adalah peringkat obligasi.

\section{HASIL DAN PEMBAHASAN}

\section{A. Uji Asumsi Klasik}

Hasil uji normalitas dengan One-Sampel Kolmogorov-Smirnov Test menunjukkan Asymp. Sig. sebesar 0,200 yang artinya lebih besar dari 0,05 menunjukkan bahwa data berdistribusi normal. Berdasarkan hasil analisis tabel diatas dengan 86 sampel data dapat diketahui bahwa semua nilai VIF dibawah 10 dan nilai tolerance diatas 0,1 artinya tidak terjadi multikolinieritas antar variabel independen dalam regresi pada penelitian ini. Berdasarkan hasil uji heteroskedastisitas diatas diketahui bahwa variabel independen diatas tingkat kepercayaan 0,05 sehingga tidak terjadi heteroskedastisitas pada model penelitian ini. Berdasarkan hasil pengujian autokorelasi, menunjukan bahwa 
D-W sebesar 1,176 yang artinya hasil tersebut termasuk diantara -2 sampai +2. Sehingga dapat disimpulkan tidak ada gejala autokorelasi pada hasil pengujian tersebut.

\section{B. Analisis Regresi Linier Berganda} Tabel 1. Analisis Regresi Berganda

\begin{tabular}{|c|c|c|c|c|c|}
\hline \multirow{3}{*}{ Model } & \multicolumn{2}{|c|}{$\begin{array}{l}\text { Unstandardized } \\
\text { Coefficients }\end{array}$} & \multicolumn{2}{|c|}{$\begin{array}{l}\text { Standardized } \\
\text { Coefficients }\end{array}$} & \multirow[b]{3}{*}{ Significance } \\
\hline & & Std. & Beta & & \\
\hline & B & Error & & $\mathrm{t}$ & \\
\hline (Constant) & 41,331 & 4,394 & & 9,407 & 0,000 \\
\hline Profitabilitas_X1 & $-22,538$ & 12,051 & $-0,155$ & $-1,870$ & 0,065 \\
\hline Likuiditas X' & 1,695 & 0,489 & 0,337 & 3,467 & 0,001 \\
\hline Leverage_X X3 & 0,455 & 0,082 & 0,450 & 5,558 & 0,000 \\
\hline Umur_Obligasi_X4 & $-1,593$ & 0,391 & $-0,258$ & $-4,073$ & 0,000 \\
\hline Ukuran_Perusahaan X5 & $-1,292$ & 0,121 & $-0,760$ & $-10,686$ & 0,000 \\
\hline
\end{tabular}

Sumber: Diolah Peneliti (2019)

Berdasarkan tabel 2 tersebut dapat diketahui bahwa persamaan regresi berganda yaitu: $\mathrm{Y}=41,331-22,538 \mathrm{X} 1+1,695$ $\mathrm{X} 2+0,455 \mathrm{X} 3-1,593 \mathrm{X} 4-1,292$ $\mathrm{X} 5+$ error

$\alpha=$ Nilai konstanta $(\alpha)$ menunjukkan nilai negatif sebesar 41,331 menyatakan bahwa apabila profitabilitas, likuiditas, leverage, umur obligasi, dan ukuran perusahaan nol maka peringkat obligasi naik sebesar 41,331 satuan.

$\beta 1=-22,538$ artinya setiap peningkatan profitabilitas sebesar satu satuan maka menyebabkan peringkat obligasi menurun sebesar - 22,538 satuan dengan asumsi variabel lain tetap.

$\beta 2=1,695$ artinya setiap peningkatan likuiditas sebesar satu satuan maka menyebabkan peringkat obligasi meningkat sebesar 1,695 satuan dengan asumsi variabel lain tetap. $\beta 3=0,455$ artinya setiap peningkatan leverage sebesar satu satuan maka menyebabkan peringkat obligasi meningkat sebesar 0,455 satuan dengan asumsi variabel lain tetap.

$\beta 4=-1,593$ artinya setiap peningkatan umur obligasi sebesar satu satuan maka menyebabkan peringkat obligasi menurun sebesar - 1,593 satuan dengan asumsi variabel lain tetap.

$\beta 5=-1,292$ artinya setiap peningkatan ukuran perusahaan sebesar satu satuan maka menyebabkan peringkat obligasi menurun sebesar - 1,292 satuan dengan asumsi variabel lain tetap.

\section{Uji Kecocokan Model}

1. Uji Koefisien Determinasi $\left(\mathrm{R}^{2}\right)$ Berdasarkan hasil diatas menunjukkan bahwa koefisiensi determinasi yang menunjukkan nilai adjusted $\mathrm{R}^{2}$ sebesar 0,764 . Hal ini berarti $76,4 \%$ variabel dependen yaitu peringkat obligasi dapat dijelaskan oleh 
variabel independen yaitu profitabilitas, likuiditas, leverage, umur obligasi dan ukuran perusahaan. Sedangkan
$23,6 \%$ dijelaskan oleh varaibel lain diluar penelitian ini.

2. Uji F

Tabel 2. Uji F

ANOVA ${ }^{\mathrm{a}}$

\begin{tabular}{lrrrrr}
\hline \multicolumn{1}{c}{ Model } & $\begin{array}{c}\text { Sum of } \\
\text { Squares }\end{array}$ & Df & $\begin{array}{c}\text { Mean } \\
\text { Square }\end{array}$ & F & Significance \\
\hline 1 & 586,971 & 5 & 117,394 & 51,756 &, 000 \\
Regression & & & & & \\
Residual & 181,459 & 80 & 2,268 & & \\
Total & 768,430 & 85 & & & \\
\hline
\end{tabular}

Sumber: Diolah Peneliti (2019)

Berdasarkan analisis menunjukkan bahwa nilai $\mathrm{F}$ hitung sebesar 51,756 dengan nilai signifikan $0,000 \leq 0,05$, maka diperoleh degree of freedom; $\alpha,(\mathrm{k}-1),(\mathrm{n}-\mathrm{k})$ atau 0,05 (5-1), (86-5) diperoleh $\mathrm{F}$ tabel sebesar 2,48 karena $\mathrm{F}$ hitung 51,756 $>$ F tabel 2,48 maka model regresi dapat diterima dan dapat digunakan untuk memprediksi profitabilitas, likuiditas, leverage, umur obligasi dan ukuran perusahaan secara bersama-sama berpengaruh signifikan terhadap peringkat obligasi.

\section{Pembahasan}

1. Hipotesis 1: Profitabilitas berpengaruh positif signifikan terhadap peringkat obligasi

Berdasarkan tabel 4 diperoleh koefisien $(\beta 1=$ 22,538 ) dengan $t$ hitung sebesar $-1,870$ dan nilai signifikan sebesar 0,065 yang artinya nilai sig $\geq 0,05$ maka diperoleh degree of freedom $=(n-k)$ atau (86-5) sebesar 81 dan diperoleh $\mathrm{t}$ tabel $=1,66388$ karena $\mathrm{t}$ hitung $-1,870<\mathrm{t}$ tabel 1,66388 maka Ho diterima dan Ha ditolak dengan profitabilitas berpengaruh negatif tidak signifikan terhadap peringkat obligasi. Dengan demikian hipotesis profitabilitas berpengaruh negatif positif signifikan terhadap peringkat obligasi ditolak.

Berdasarkan hasil uji hipotesis diatas profitabilitas berpengaruh negatif tidak signifikan terhadap peringkat obligasi, yang artinya hasil profitabilitas berpengaruh negatif hanya sedikit bahkan hasil ini memberikan arti yaitu berapapun nilai ROA entah kecil atau besar tidak akan memberikan pengaruh pada rating obligasi yang telah diterbitkan oleh perusahaan pemeringkat, Hasan \& Dana, (2018). Berpengaruh negatif apabila semakin tinggi profitabilitas suatu perusahaan maka semakin rendah peringkat obligasi perusahaan tersebut tetapi berpengaruh negatif hanya sedikit, meskipun perusahaan memperoleh laba yang tinggi tetapi laba tersebut digunakan perusahaan untuk membayar kewajiban jangka pendek maupun jangka panjang. Karena dalam penelitian ini menggunakan perusahaan sektor 
keuangan, terdapat arus kas keluar seperti penarikan deposito oleh nasabah dan pemberian kredit, apabila arus kas keluar jauh lebih besar daripada arus kas masuk perusahaan dapat mengalami keadaan tidak likuid, hal ini disebabkan karena perusahaan sering mengalami kredit bermasalah yaitu tidak terbayarnya sebagian atau keseluruhan kredit yang disalurkan oleh perusahaan, yang mengakibatkan likuiditas perusahaan menurun sehingga tidak adanya dana yang masuk yang menjadi sumber likuiditas perusahaan, dan dapat berpengaruh pada profitabilitas perusahaan yang menurun, dengan tingkat peringkat obligasi yang tetap tinggi (Faradi, 2015).

$$
\text { Penurunan tingkat }
$$

profitabilitas salah satunya disebabkan karena tingginya arus kas keluar pada perusahaan sektor keuangan tersebut, tetapi peringkat obligasi perusahaan tetap peringkat obligasi tinggi (high investment grade), oleh sebab itu variabel profitabilitas saja tidak dapat digunakan untuk menilai peringkat obligasi melainkan ada faktor lain yang dapat digunakan untuk penilaian obligasi. Sehingga teori keagenan menurut Jansen dan Meckling (1976) yang merupakan suatu kondisi yang terjadi pada suatu perusahaan dimana perusahaan sebagai pelaksana yang disebut sebagai agen dan investor sebagai principal membangun suatu kontrak kerjasama yang disebut dengan "nexus of contract", kontrak kerjasama ini berisi kesepakatan-kesepakatan yang menjalankan bahwa pihak manajemen perusahaan harus bekerja secara maksimal untuk memberi kepuasan kepada investor terkait dengan laba yang tinggi tersebut gagal. Apabila profitabilitas yang tinggi tidak memberikan kepuasan kepada investor sebagai principal dengan perolehan laba yang tinggi ketika peringkat obligasi dalam keadaan tinggi, maka dengan alasan untuk membayar kewajiban jangka pendek maupun jangka panjang pada perusahaan sehingga perusahaan belum mampu membagi keuntungannya untuk investor (Fahmi, 2014).

2. Hipotesis 2: Likuiditas berpengaruh positif signifikan terhadap peringkat obligasi Berdasarkan tabel 4 diperoleh koefisien $(\beta 2=1,695)$ dengan $t$ hitung sebesar 3,467 dan nilai signifikan sebesar 0,001 yang artinya nilai sig $\leq$ 0,05 maka diperoleh degree of freedom $=(\mathrm{n}-\mathrm{k})$ atau (86-5) sebesar 81 dan diperoleh $t$ tabel $=1,66388$ karena t hitung 3,467 $>\mathrm{t}$ tabel 1,66388 maka Ho ditolak dan Ha diterima dengan likuiditas berpengaruh positif signifikan terhadap peringkat obligasi. Sehingga hipotesis likuiditas berpengaruh positif signifikan terhadap peringkat obligasi diterima.

Menurut Azani dkk. (2017) menyatakan bahwa tingkat likuiditas suatu obligasi sangat penting dalam memengaruhi harga obligasi. Obligasi dengan tingkat likuiditas yang tinggi cenderung 
memiliki harga yang lebih tinggi dibandingkan dengan obligasi dengan tingkat likuiditas yang rendah. Sehingga investor akan lebih memilih untuk berinvestasi pada obligasi yang memiliki tingkat likuiditas yang tinggi meskipun harga yang ditawarkan untuk obligasi tersebut tinggi, karena dengan tingkat likuiditas yang tinggi investor menilai perusahaan akan mampu memenuhi kawajiban dalam membayar bunga obligasi maupun pokoknya pada waktu jatuh tempo. Sehingga sesuai teori sinyal menurut bahwa likuiditas yang tinggi dapat memberikan sinyal positif kepada investor untuk berinvestasi di perusahaan tersebut. Maka dapat disimpulkan sesuai dengan hasil pengujian hipotesis diatas bahwa likuiditas berpengaruh positif signifikan terhadap peringkat obligasi. Hasil tersebut sejalan dengan penelitian yang dilakukan oleh Azani dkk. (2017), Hidayat (2018), bahwa likuiditas berpengaruh positif signifikan terhadap peringkat obligasi.

3. Hipotesis 3: Leverage berpengaruh positif signifikan terhadap peringkat obligasi

Berdasarkan tabel 4 diperoleh koefisien $(\beta 3=0,455)$ dengan $\mathrm{t}$ hitung sebesar 5,558 dan nilai signifikan sebesar 0,000 yang artinya nilai sig $\leq$ 0,05 maka diperoleh degree of freedom $=(\mathrm{n}-\mathrm{k})$ atau (86-5) sebesar 81 dan diperoleh $\mathrm{t}$ tabel $=1,66388$ karena $t$ hitung 5,558 $>\mathrm{t}$ tabel 1,66388 maka Ho ditolak dan Ha diterima dengan leverage berpengaruh positif signifikan terhadap peringkat obligasi. Sehingga hipotesis leverage berpengaruh positif signifikan terhadap peringkat obligasi diterima.

Koefisien yang bernilai positif memiliki arti bahwa semakin tinggi tingkat leverage perusahaan, maka akan semakin tinggi peringkat obligasi yang diperoleh. Dalam Keputusan Menteri Keuangan Nomor 1002/KMK.04/1984 tentang Penentuan Perbandingan antara Utang dan Modal Sendiri, penetapan besarnya perbandingan antara utang dan modal sendiri (debt equity ratio) ditetapkan setinggi-tingginya tiga dibanding satu $(3: 1)$ atau batas kewajaran utang sebuah perusahaan adalah maksimal tiga kali modalnya, atau leverage-nya $300 \%$. Dapat dikatakan sesuai teori sinyal menurut Spence (1973) bahwa nilai leverage yang tinggi pada perusahaan akan memberikan sinyal yang positif kepada investor untuk menanamkan modalnya didalam perusahaan tersebut. Namun, penggunaan utang yang tinggi sejatinya menunjukkan default risk yang tinggi pula pada perusahaan. Hasil penelitian ini sejalan dengan peneliti sebelumnya, yaitu Mardiyanti dkk. (2015), Azani dkk. (2017), Widiyastuti (2016), Dwitayanti (2018), Sakinah dkk. (2017), yang menyatakan bahwa leverage berpengaruh positif dan signifikan terhadap peringkat obligasi.

4. Hipotesis 4: Umur obligasi berpengaruh negatif signifikan terhadap peringkat obligasi 
Berdasarkan tabel 4 diperoleh koefisien $(\beta 4=-$ $1,593)$ dengan $t$ hitung sebesar 4,073 dan nilai signifikan sebesar 0,000 yang artinya nilai sig $\leq 0,05$ maka diperoleh degree of freedom $=(\mathrm{n}-\mathrm{k})$ atau (86-5) sebesar 81 dan diperoleh $\mathrm{t}$ tabel $=-1,29209$ karena $\mathrm{t}$ hitung $-4,073<\mathrm{t}$ tabel $-1,66388$ maka Ho ditolak dan $\mathrm{Ha}$ diterima dengan umur obligasi berpengaruh negatif signifikan terhadap peringkat obligasi. Sehingga hipotesis umur obligasi berpengaruh negatif signifikan terhadap peringkat obligasi diterima.

Tensia, Rizal \& Supriyono, (2015) menyatakan bahwa umur obligasi dapat memengaruhi peringkat obligasi. Obligasi yang memiliki umur yang lebih panjang akan memiliki risiko kegagalan dalam memenuhi kewajibannya lebih besar sehingga peringkat obligasi yang didapat kecil sedangkan obligasi yang memiliki umur obligasi lebih pendek memiliki risiko kegagalan dalam memenuhi kewajibannya lebih kecil sehingga dapat meningkatkan peringkat obligasi. Sehingga dapat dikatakan pada teori sinyal menurut Spence (1973) bahwa umur obligasi perusahaan akan memberikan sinyal yang negatif terhadap investor dalam berinvestasi. Hasil penelitian ini sejalan dengan peneliti sebelumnya, yaitu Tensia, Rizal \& Supriyono, (2015), menyatakan bahwa umur obligasi berpengaruh negatif signifikan terhadap peringkat obligasi.
5. Hipotesis 5: Ukuran perusahaan berpengaruh positif signifikan terhadap peringkat obligasi

Berdasarkan tabel 4 diperoleh koefisien $(\beta 5=$ $1,292)$ dengan $t$ hitung sebesar 10,686 dan nilai signifikan sebesar 0,000 yang artinya nilai sig $\leq 0,05$ maka diperoleh degree of freedom $=(n-k)$ atau (86-5) sebesar 81 dan diperoleh $\mathrm{t}$ tabel $=1,29209$ karena $\mathrm{t}$ hitung $-10,686<\mathrm{t}$ tabel 1,66388 maka Ho diterima dan $\mathrm{Ha}$ ditolak dengan ukuran perusahaan berpengaruh negatif signifikan terhadap peringkat obligasi. Sehingga hipotesis ukuran perusahaan berpengaruh positif signifikan terhadap peringkat obligasi ditolak.

Hasil tersebut didukung oleh Rukmana (2016), yang menyatakan bahwa walaupun ukuran perusahaan bernilai tinggi tetapi bisa bernilai berpengaruh negatif terhadap peringkat obligasi jika perusahaan tersebut terkena gagal bayar "default" sehingga menurunkan peringkat obligasi tersebut. Seperti yang terdapat pada empat bank besar di Yunani yang terkena penurunan peringkat obligasi menjadi CCC karena mereka terkena gagal bayar. Empat bank besar itu yaitu National Bank of Greece, Piraeus Bank, Eurobank Ergasias dan Alpha Bank (https://internasional.kontan.co.i d/news/fitchpangkasperingkate mpatbankyunani).

Hal tersebut membuktikan bahwa ukuran perusahaan yang besar/tinggi tidak menjamin peringkat obligasi yang diperoleh tinggi/kategori baik, menurut 
fenomena diatas ada beberapa faktor yang menyebabkan peringkat obligasi turun salah satunya yaitu perusahaan terkena risiko gagal bayar (default). Jadi, fenomena tersebut dapat mendukung hasil hipotesis ke-5, profitabilitas berpengaruh negatif signifikan terhadap peringkat obligasi. Sehingga menurut teori Spence (1973), bahwa ukuran perusahaan dapat memberikan sinyal terhadap peringkat obligasi benar terbukti dengan memberikan sinyal negatif. Jadi dapat dikatakan bahwa ukuran perusahaan berpengaruh negatif signifikan terhadap peringkat obligasi.

\section{KESIMPULAN}

Berdasarkan hasil analisis dan pembahasan yang telah dilakukan, maka diperoleh simpulan sebagai berikut:
A. Profitabilitas berpengaruh negatif tidak signifikan terhadap peringkat obligasi.
B. Likuiditas berpengaruh positif signifikan terhadap peringkat obligasi.
C. Leverage berpengaruh positif signifikan terhadap peringkat obligasi.
D. Umur obligasi berpengaruh negatif signifikan terhadap peringkat obligasi.
E. Ukuran perusahaan berpengaruh negatif signifikan terhadap peringkat obligasi.

\section{DAFTAR PUSTAKA}

Anandasari, L.P.S.K, \& Sudjarni, L.K. (2017). Pengaruh Likuiditas, Waktu Jatuh Tempo dan Kupon terhadap Perubahan Harga Obligasi Korporasi di BEI. E-Jurnal Manajemen Unud, 6(6), $3283-3313$.
Azahro, Siva. (2016). Perlindungan Hukum Investor Obligasi terhadap Risiko Gagal Bayar (Default). Diponegoro Law Review, 5(2).

Azani, K.P., et al. (2017). Pengaruh Likuiditas, Leverage dan Pertumbuhan Perusahaan terhadap Peringkat Obligasi (Studi Empiris Pada Perusahaan Non Keuangan dan Non Perbankan yang Diperingkat oleh PT. PEFINDO Tahun 2011 2015). e-Proceeding of Management, 4(1).

Blesia, J.U., \& Dita, R.P. (2016). Key Aspects of the Bond Ratings in Indonesia. Asian Journal of Economics, Business and Accounting, 1(3), 1 - 14.

Bursa Efek Indonesia. (2016). Retrieved 2 Februari 2019 from www.idx.co.id.

Dwitayanti, Y. (2018). Analisis Pengaruh Rasio Leverage terhadap Peringkat Obligasi Pada Perusahaan yang Terdaftar di Bursa Efek Indonesia. Jurnal Akuntanika, 4(1).

Fahmi, I. (2013). Rahasia Saham dan Obligasi. Jakarta Selatan: CV. Alvabeta.

Faizah, Y.L.N. (2019). Pengaruh Laverage Maturity dan Size Perusahaan terhadap Yield Obligasi dengan Peringkat obligasi sebagai Variabel Intervening. Journal of Economic, Management, Accounting and Technologi (JEMATech), 2(1).

Fahmi, I. (2014). Manajemen Keuangan Perusahaan dan Pasar Modal. Jakarta: Mitra Wacana Media.

Faradi, A.M., \& Supriyanto. (2015). Faktor-Faktor yang Mempengaruhi Peringkat Obligasi pada Perusahaan Non Keuangan yang Terdaftar di Bursa Efek Indonesia. Jurnal Ekonomi dan Bisnis, 2(1).

Hamida, L. (2017). Pengaruh Likuiditas dan Leverage terhadap Yield Sukuk dengan Peringkat Sukuk sebagai Variabel Intervening. Ekobis, 18(1), $71-78$. 
Hartono, J. (2017). Teori Portofolio dan Analisis Investasi Edisi Kelima. Jakarta: Rajawali Press.

Hasan, D.A., \& Dana, I.M. (2018). Influence of Profitability, Liquidity and Maturity Guarantee of The Highest Bond Rating. Management E-Journal, 7(2), 643 - 673.

Henny. (2016). Pengaruh Faktor Akuntansi terhadap Prediksi Peringkat Obligasi. Jurnal Akuntansi, 20(1), 52 - 69.

Hery, (2017). Akuntansi (Mengulas Berbagai Hasil Peelitian Terkini dalam Bidang Akuntansi dan Keuangan). Jakarta: PT. Gramedia.

Hidayat, W.W. (2018). Pengaruh Leverage dan Likuiditas terhadap Peringkat Obligasi: Studi Kasus Perusahaan Non Keuangan Di Indonesia. Jurnal Riset Manajemen dan Bisnis (JRMB), 3(3), 387 - 394.

Jensen, M.C., \& Meckling, W.H. (1976). Theory of the firm: Managerial behavior, agency costs and ownership structure. Journal of Financial Economics, 3, 305 - 360.

Lukman, T. (2017). Analisis Faktor-Faktor yang Mempengaruhi Peringkat Obligasi di Bursa Efek Indonesia. UII Jurnal.

Latumaerissa, J.R. (2017). Bank dan Lembaga Keuangan Lain (Teori dan Kebijakan). Jakarta: Mutiara Wacana Media.

Mardiyati, U., Utami, N.S.G., \& Ahmad, N.G. (2015). The Effect of Profitability, Liquidity, Leverage and Firm Size toward Bond Rating on Non Financial Institution Listed in Indonesia Stock Exchange Period 2010-2014. Jurnal Riset Manajemen Sains Indonesia (JRMSI), 6(2).

Pinandita, W.A., \& Suryantini, N.P.S. (2016). Pengaruh Profitabilitas, Rasio Solvabilitas, Ukuran Perusahaan dan Reputasi Auditor terhadap Peringkat Obligasi pada
Sektor Perbankan. E-Jurnal Manajemen Unud, 5(10).

Rukmana, L.N. (2016). The Effects of Financial Ratios and Firm Size on The Bond Ratings of Banking Companies Listed in Indonesia Stock Exchange in 2011-2015. Jurnal Pendidikan dan Ekonomi, 5(6).

Sakinah, P., Paminto, A., \& Kadafi. A.M., (2017). Analisis Faktor Keuangan dan Non Keuangan yang Mempengaruhi Prediksi Peringkat Obligasi (Studi empiris pada perusahaan penerbit obligasi yang terdaftar di Bursa Efek Indonesia periode 2012-2014). Akuntabel, 14(1).

Sari, K.S.N.M., \& Badjra, I.B. (2016). Pengaruh Likuiditas, Ukuran Perusahaan, Leverage dan Jaminan terhadap Peringkat Obligasi pada Sektor Keuangan. E-Jurnal Manajemen Unud, 5(8), 5041-5069.

Spence, M. (1973). Job market signaling. Quarterly Journal of Economics, 87, 355- 374.

Sugiyono. (2013). Metode Penelitian Pendidikan Pendekatan Kuantitatif, Kualitatif, dan R\&D. Bandung: Alfabeta.

Suliyanto. (2018). Metode Penelitian Bisnis. Yogyakarta: Penerbit Andi Offset.

Suwarti, A., \& Titis K. (2015). Pengaruh Profitabilitas, Leverage, Likuiditas dan Produktifitas terhadap Peringkat Obligasi. Prosiding Seminar Nasional Multi Disiplin Ilmu \& Call For Papers Unisbank Ke-3 (Sendi_U 3) 2017.

Tensia, O.K., Yaya, R., \& Supriyono, E., (2015). Variabel-Variabel yang Dapat Mempengaruhi Peringkat Obligasi (Studi Kasus Perusahaan Non Keuangan dan Non Jasa yang Terdaftar di Bursa Efek Indonesia). 6(2).

Utari, D., Purwati, A., \& Prawironegoro, D. (2014). Manajemen Keuangan 
DERIVATIF: Jurnal Manajemen

Vol. 14 No. 1 April 2020

(ISSN Cetak 1978-6573) (ISSN Online 2477-300X)

(Kajian Praktik dan Teori dalam Megelola Keuangan Organisasi Perusahaan) Edisi Revisi. Jakarta: Mitra Wacana Media.

Widiastuti, N.P.T., \& Rahyuda, H. (2016). Pengaruh Pertumbuhan, Rasio Likuiditas, Maturity dan Rasio Aktivitas terhadap Peringkat Obligasi pada Perusahaan Jasa. EJurnal Manajemen Unud, 5.

Widiyastuti, T. (2016). Pengaruh Rasio Leverage dan Rasio Profitabilitas Terhadap Peringkat Obligasi (Studi Pada Perusahaan Manufaktur Yang Terdapat di BEI ). Jurnal Kompilek, 8(1). 